\title{
Label Free C-reactive Protein Detection Based on An Electrochemical Sensor for Clinical Application
}

\author{
Xuehua Bing ${ }^{1, *}$, Guorong Wang $^{2}$ \\ ${ }^{1}$ Department of Cardiovascular Surgery, the Central Hospital of Linyi, Shandong Province, 276400, \\ Linyi, P. R. China \\ ${ }^{2}$ Department of the Infection Control Section, the Central Hospital of Linyi, Shandong Province, \\ 276400, Linyi, P. R. China \\ *E-mail: xuehuabing@foxmail.com
}

doi: $10.20964 / 2017.07 .60$

Received: 4 April 2017 / Accepted: 28 April 2017 / Published: 12 June 2017

This study describes the facile and effective fabrication of electrochemical biosensors based on a glassy carbon electrode coated with graphene quantum dots (GQD). The prepared electrode shows a desirable electrochemical response, since the graphene is favourably conductive. The prepared GQD designed biosensor has been employed for C-reactive protein (CRP) detection in blood serum. Herein, charge transfer resistance variations were significantly target specific, showing a linear relationship with $\log$ CRP concentration $(0.5-70 \mathrm{nM})$ and a low limit of detection (LOD) of $176 \mathrm{pM}$. This technique could be employed to achieve one-step CRP detection and has the potential to be applied to clinical atrial fibrillation (AF) analysis after CABG.

Keywords: Atrial fibrillation; Electrochemical sensor; C-reactive protein; Graphene quantum dots; CABG

\section{FULL TEXT}

(C) 2017 The Authors. Published by ESG (www.electrochemsci.org). This article is an open access article distributed under the terms and conditions of the Creative Commons Attribution license (http://creativecommons.org/licenses/by/4.0/). 